\title{
Reduced Consumption for Transport due to Population Ageing? An Analysis of Expenditures of Private Households in the European Union and Potential Implications for the Public Sector
}

\author{
Birgit Aigner-Walder \\ Carinthia University of Applied Sciences, Austria \\ b.aigner-walder@cuas.at \\ Thomas Döring \\ Darmstadt University of Applied Sciences, Germany \\ thomas.doering@h-da.de
}

\section{ABSTRACT}

\begin{abstract}
The paper focuses on potential effects of the ageing of the population on consumption expenditures of private households in the field of transport. Theoretical considerations as well as previous empirical results suggest that older households consume different goods and services than younger ones due to changing preferences and needs by increasing age. Possible consequences of these changes for goods and services in the transport sector are in focus. The expenditures of European households on transport based on the national household budget surveys of the 28 member countries of the European Union are analysed. The results suggest that expenditures in transport decrease at retirement age in all considered countries. Moreover, the structure of goods and services consumed in the transport sector changes over the life cycle of a private household, with implications for the public sector due to the ageing of the population to be expected.
\end{abstract}

Key words: household expenditures, private consumption, transportation goods and services, ageing, public transport.

JEL:D12

\section{Introduction}

Looking at statistics on the population structure by age, one would have to search for countries where the ageing of the population is not directly visible. The long-term change of the population structure from a younger to an older one, also known as demographic change, is a worldwide observable 


\section{Birgit Aigner, Thomas Döring}

development. This development can be led back to a decrease in the fertility rate, i.e. the number of birth per woman, accompanied by an increase in life expectancy (Schimany, 2003). Although these two demographic trends are worldwide visible, its rapidity and the recent status of the so called demographic transition vary greatly by continent, nation, province, and even region. Despite of the two mentioned relevant components (fertility rate, life expectancy) also the current population structure (e.g. number of women at childbearing age), as well as migration patterns play an important role (e.g. outmigration of young people) for the changing age distribution.

According to UN comparisons, the ageing of the population is most advanced in Europe. 19 out of the 20 countries of the world with the highest share of people aged 60 or above are situated in Europe. The only exception is Japan, which is ranked number one (United Nations, 2013). With more than a fifth of the population being 65 years or older Italy, Greece and Germany are the countries with the oldest population in Europe. On the contrary, the countries with the youngest population within the European Union are Ireland, Luxembourg and Slovakia, with a share of older people between $13 \%$ and $14 \%$. During the last decade there has already been an increase in the share of population aged 65 and more of up to 5 percentage points within the countries of the European Union (Eurostat, 2017). And the ageing of the population will be going on in all countries of the European Union: According to the recent projections the share of the older population in the EU as a whole is presumably going to increase from 18\% to 28\% in 2060 (European Commission, 2015).

The increase of the older population will have various effects on the economy. The ageing of the population leads to a reduction of the population in working age being a challenge for the labour market, productivity and public budgets. The European Commission projects a stabilization of total labour supply until 2023, followed by a decline of 8.2\% between 2023 and 2060; increases in the participation rates of female and older workers as well as migration inflows already being considered. The decreased labour input will also influence the output growth negatively, leaving labour productivity growth as sole source of potential output growth. Regarding the budgetary projections, the changes to be expected in public age-related expenditures (pensions, health care, long-term care and education) will increase public expenditures by almost 2 percentage points of GDP between 2013 and 2060 (European Commission, 2015).

Besides these macroeconomic trends and challenges the ageing of the population also influences the consumption expenditure structure of the population. Older people consume different goods and services than younger ones and also the level of total consumption expenditures varies over the life cycle. The paper at hand highlights the question of how the consumption expenditures of goods and services in the field of transport changes over the life cycle and draws potential implications of the ageing of the population on aggregate demand within the transport sector. Therefore, theoretical 
considerations and previous empirical results on differences in private consumption expenditures by age with a special focus on the transport sector are in focus in chapter 2. Subsequently, chapter 3 gives an overview of the following empirical investigation and the data considered. Chapter 4 demonstrates results on the level of expenditures for transport over the life cycle of households within the EU, while in chapter 5 also the structure of these expenditures is highlighted. The paper closes with an analysis of potential reasons and implications of the observed trends (chapter 6). This includes a discussion of implications for the public sector (chapter 7).

\section{Theoretical Considerations and Previous Empirical Results}

According to microeconomic consumer theory, the decision of a household on which goods and services to consume is dependent on the income of the household, the prices of goods and services as well as the preferences of the household. Hereby theory states that the choice of goods and services is determined by the preferences of the household, with the aim to maximize utility under the given income of the household and prices of the goods and services (Pindyck and Rubinfeld, 2005; Woeckener, 2006; Mankiw and Taylor, 2014). Considering the level of consumption expenditures in general, in particular the income of the household is of relevance. Furthermore, objective indicators (as the interest rate or taxes), subjective needs, psychological affections and habits play a role (Keynes, 1936). Under the life cycle theory (Modigliani and Brumberg, 1966) a household aims to smooth consumption over the life cycle. This implies saving during the working life and dissaving in retirement, as income drops. The empirically seen hump-shaped form of consumption is according to Modigliani (1986) mainly caused by a change in the number of household members.

Having in mind the demographic change, the age of household members has an influence on the income of the household, the number of household members, as well as the preferences of the household. The income of the household as well as the number of household members show a humpshaped form over the life cycle, with the consequence of lower consumption levels at the beginning and the end of a households life cycle (Dyan, Edelberg and Palumbo, 2009; Foot and Gomez, 2006; Fernández-Villaverde and Krueger, 2002). But the consumption behaviour of a household varies also greatly by age due to differing preferences and needs with increasing age of the household's representative (Solomon, 2014). For example, one might expect that young people will have higher expenditures in the field of education, while older people demand more goods and services in the health sector. Furthermore, the consumption structure differs by age cohort due to the comparable historical, economical or societal framework people went through (Evans, Jamal and Foxall, 2009).

Empirical results on the level of consumption over the life cycle for Germany based on the sample survey of income and expenditure of the years 1993 to 2003 show that households in the age between 50 and 64 years have the 
highest consumption level. When entering retirement age consumption drops by approx. $20 \%$, and those having a representative over 75 years show again a reduction in consumption of 20\% (Bundesministerium für Familie, Senioren, Frauen und Jugend, 2007). Moreover, the concave development of consumption over the life cycle appears in empirical work of Deutsche Bank Research (2007) for Germany, Aigner-Walder (2012) for Austria, FernándezVillaverde and Krueger (2002) for the US or Deaton and Paxson (1994) for Taiwan. Fernández-Villaverde and Krueger (2002) find that the hump-shaped form of consumption can be explained by the changing household size over the life cycle by $50 \%$. For the lower consumption levels in younger ages they assume lower income levels, higher future insecurity and low possibilities for credits as potential explanations. The drop in consumption at higher ages, also known as retirement-consumption puzzle, has been investigated profoundly in empirical studies, especially as consumption drops at higher rates than income. Potential explanations are a decrease of work related expenses and a higher relevance of own production (Hurd and Rohweder, 2005; Lührmann, 2009) as well as shocks in retirement (e.g. height of retirement benefits, health related shocks; Banks, Blundell and Tanner, 1998).

Besides changes in the consumption level also differences in consumption structure by age are empirically shown by various studies. While Buslei, Schulz and Steiner (2007) as well as Lehmann (2004) illustrate age-specific consumption patterns for German households, they also find a significant influence of the variable age on all consumption categories. Differences in the consumption structure by age are also depicted by Deutsche Bank Research (2007, again for Germany), Foot and Gomez (2006) for Great Britain, AignerWalder (2015) as well as Aigner-Walder and Döring (2012) for Austria or Martins et al. (2005) for the OECD countries. Their main findings are quite similar: expenditure shares for housing, water and fuel as well as health increase by age, while expenses for transport decrease at higher ages. Projections on the effects of the ageing of the population on the aggregate demand of private households, based on empirical findings, result in increases in the budget shares for health and housing, while the transport sector is expected to lose consumption shares (Martins et al., 2005; Foot and Gomez, 2006; Deutsche Bank Research, 2007; Buslei, Schulz and Steiner, 2007; Aigner-Walder, 2015). For Germany, the decrease in expenditures in transport is quantified by $5 \%$ up to 2035 (Bundesministerium für Familie, Senioren, Frauen und Jugend, 2007).

Having in focus private consumption, in the sense of expenditures for goods and services, in the field of transport, the analysis so far suggests, that households spend lower shares of their total consumption expenditures for transport at higher ages. As consumption is in general lower after retirement a potential reduction in aggregate demand of transport goods and services would be the outcome with the population ageing. Within the following considerations, the consumption expenditures for transport over the life cycle within the countries of the European Union will be in focus, with the aim to get a deeper insight if the stated thesis can be generalized, and in order to 
highlight potential country-specific differences between different member states.

\section{Data Basis and Methodology}

For the analysis at hand data on a household's consumption expenditures as well as socio-demographic variables like the age of the household are of relevance. As the whole European Union is of interest, comparable data for all 28 countries is needed. Consequently, the data of the Household Budget Surveys (HBS) has been considered. The HBS are national sample surveys of households, conducted in all EU member states, focusing on the expenditures of the households on different kinds of consumer goods and services over a specified time period. These surveys are mainly carried out to provide the weights for the Consumer Price Index (CPI) (Eurostat, 2015). For the categorization of the goods and services the Classification of Individual Consumption According to Purpose (COICOP) is taken into account, resulting in twelve different consumption groups, as represented in Table 1. The budget category transport can be disaggregated into the purchase of vehicles, the operation of personal transport equipment and transport services.

Table 1. Categorization of goods and services according to COICOP

\begin{tabular}{l} 
CP01: Food and non-alcoholic beverages \\
\hline CP02: Alcoholic beverages, tobacco and narcotics \\
\hline CP03: Clothing and footwear \\
\hline CP04: Housing, water, electricity, gas and other fuels \\
\hline CP05: Furnishings, household equipment and routine maintenance of the house \\
\hline CP06: Health \\
\hline CP07: Transport \\
\hline CP07.1: Purchase of vehicles \\
\hline CP07.2: Operation of personal transport equipment \\
\hline CP07.3: Transport services \\
\hline CP08: Communication \\
\hline CP09: Recreation and culture \\
\hline CP10: Education \\
\hline CP11: Restaurants and hotels \\
\hline CP12: Miscellaneous goods and services \\
\hline
\end{tabular}

Source: Eurostat (2015), own illustration.

Eurostat publishes the HBS data on individual countries and European aggregates every five years. For the following analysis the most recent available HBS data of 2010 has been taken into account. It is available for all 28 member states. Despite of aims of harmonization there are still methodological differences given between the national surveys carried out 
e.g. in terms of definitions, the structure or the imputation of owner-occupier imputed rent. Furthermore, for those countries which did not have the survey year matching the reference year of 2010, price adjustments have been carried out (Eurostat, 2015).

From a methodological point of view, the paper uses descriptive statistics to analyse differences in consumption expenditures for transport goods and services of private households within the European Union. Besides distinctions in the mean expenditures for transportation over the life cycle within the 28 countries in general, the structure of transportation goods and services is in focus. For the age differentiation households of the following four age categories are considered: less than 30 years, from 30 to 44 years, from 45 to 59 years and 60 years or more.

\section{Share of Expenditures for Transport Over the Life Cycle of European Households}

Before having a detailed look at the consumption expenditures for transport over the life cycle, it seems of interest to get a general overview of how much households spend on goods and services in the field of transport compared to other consumption categories. As visible in Figure 1, a representative household within the European Union spends on average $12.3 \%$ of total expenditures on transport. With that quite high amount transport is found directly after expenditures for housing, water, electricity, gas and other fuels (28.7\%) and food and non-alcoholic beverages (16.2\%). The three mentioned consumption categories are summing up to almost $60 \%$ of total expenditures, whereas all other consumption shares amount each to less than $10 \%$ of total budget. For the consumption categories health (3.1\%), communication (3.1\%), alcoholic beverages, tobacco and narcotics (2.4\%) and education (1.1\%) even less than $5 \%$ of the budget is spent. The budget structure of households within the European Union reveals the high relevance of expenditures for transport.

As one already might expect, the consumption structure is very much depending on the households' origin, too. On the one hand income and prices differ throughout the European Union, and on the other hand consumption habits depend on culture, consumption possibilities, legal settings, etc. For transportation goods and services differences in prices of fuels or highway tolls as well as prices for transport modes (e.g. public or private transport services, specific car types) or varying preferences in the use of transport vehicles (e.g. mainly small cars vs. SUVs) may affect the structure of expenditures. Moreover, in the case of transport also settlement structures, distances between cities, topographic characteristics or the supply of public transport are important influential factors.

As Figure 2 reveals, the budget share of households on transport varies greatly between EU member states, with a minimum of $4.6 \%$ and a maximum of $17.5 \%$. While Finland (17.5\%), the United Kingdom (15.4\%) and Austria 
(15.0\%) are those countries with the highest household budget shares for transport, Slovakia, Bulgaria and Romania are with $7.2 \%, 5.3 \%$ and $4.6 \%$ those countries, where household spend least.

Figure 1. Average Consumption structure of private households within the European Union, 2010

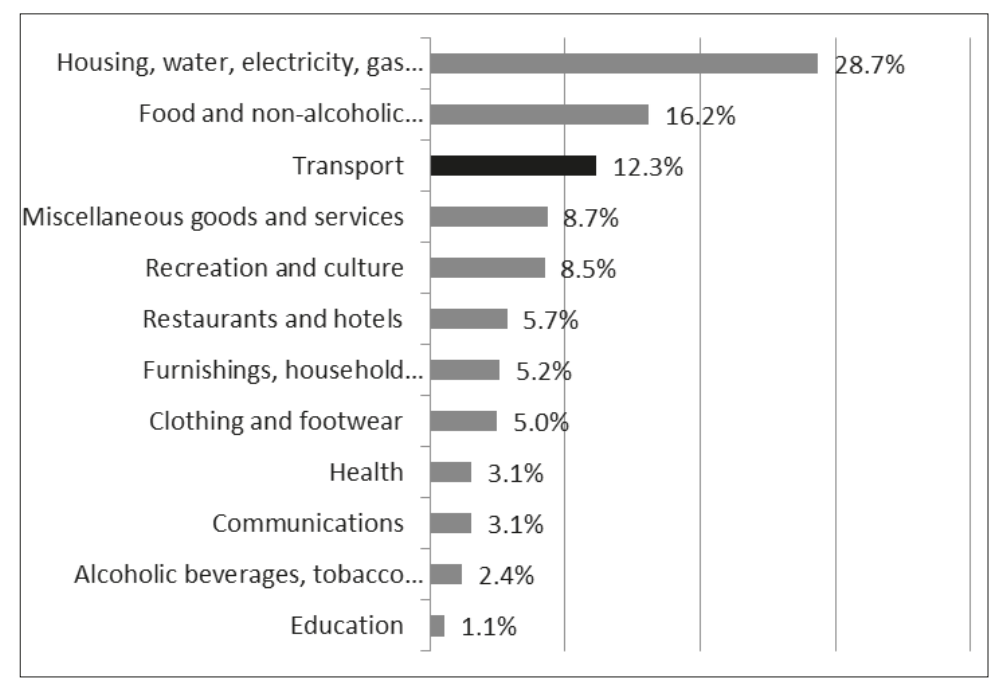

Source: Eurostat (2015), own calculation.

Figure 2. Share of private households transport expenditures in total consumption expenditures in the EU28 countries, 2010

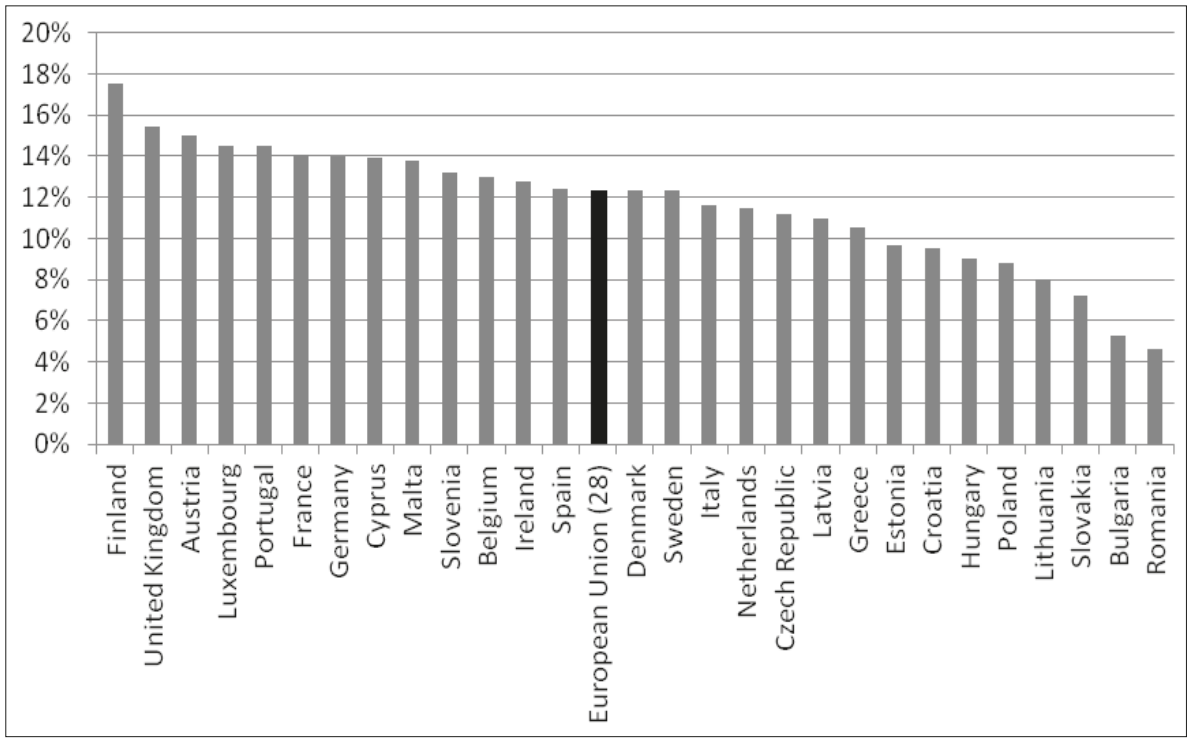

Source: Eurostat (2015), own calculation. 
In the following paragraphs age-specific consumption expenditure patterns are analysed. Figure 3 gives a general overview of the consumption profile on transport within a household's life cycle in the European Union. The reduction of private expenditures for goods and services in transport is - in accordance with previous empirical results - also clearly visible for households within the European Union. While households with a household representative aged less than 30 years spent $14.1 \%$ of total expenditures on transport, the share is already slightly reduced by those between 30 and 44 years (13.6\%) and 45 to 59 years (13.4\%). But households with a representative at the age of 60 or more spend much less on transport: the expenditure share decreases by almost four percentage points to $9.5 \%$.

Figure 3. Budget share on transport over the life cycle of a household in the European Union, 2010

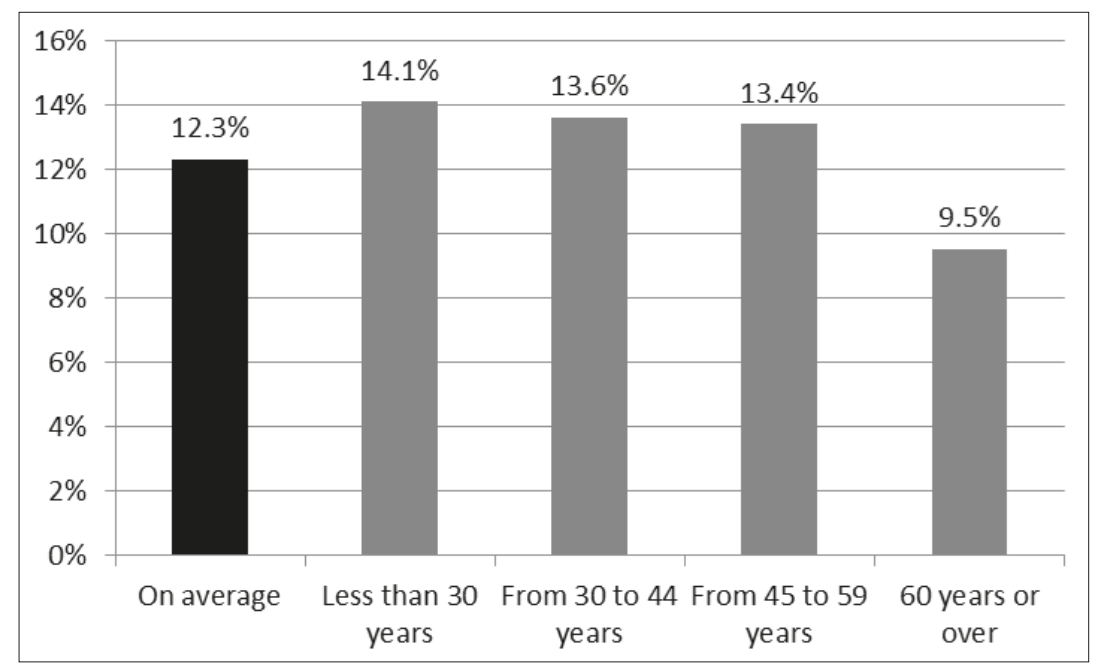

Source: Eurostat (2015), own calculation.

A glimpse on the budget shares for transport over the life cycle on national level reveals that the lowest expenditure share for transport is within the oldest age group (60 years or over) throughout all 28 member states (see Table 2). On average, the expenditures of households for transport decrease by almost 4 percentage points, when reaching retirement age. The highest downturn of relative expenses on transport can be found in Portugal (7.2 percentage points), the lowest in the Netherlands (1.2 percentage points). Moreover, in 12 out of the 28 countries, the expenditure share for transport is already reduced at the age between 45 and 59 years. In 7 countries the share spent for transport decreases even steadily by age (see marked fields in Table 2). Nevertheless, it has to be kept in mind that the expenditure share for transport in the considered age groups varies greatly throughout the European Union: Households with a representative aged 60 years or over spent between $2.5 \%$ in Romania and $14.4 \%$ in Finland of their budget for transport goods and services. 
The data of the Household Budget Survey suggests that the downturn of consumption expenditures in the field of transport relative to total expenditures seems to be generally visible. Potential reasons and consequences of these results under the perspective of the ageing of the population are discussed in chapter 6 . But before doing so, a more detailed view on the structure of expenditures in the field of transport is given in section 5 .

Table 2. Average budget share for transport over the life cycle within the EU28 countries, 2010

\begin{tabular}{|c|c|c|c|c|}
\hline Country & $\begin{array}{c}\text { Less than } 30 \\
\text { years }\end{array}$ & $\begin{array}{c}\text { From } 30 \text { to } 44 \\
\text { years }\end{array}$ & $\begin{array}{c}\text { From } 45 \text { to } 59 \\
\text { years }\end{array}$ & $\begin{array}{c}60 \text { years or } \\
\text { over }\end{array}$ \\
\hline Austria & $15.5 \%$ & $15.6 \%$ & $16.4 \%$ & $12.0 \%$ \\
\hline Belgium & $14.9 \%$ & $15.2 \%$ & $12.7 \%$ & $10.6 \%$ \\
\hline Bulgaria & $6.9 \%$ & $6.9 \%$ & $6.2 \%$ & $4.0 \%$ \\
\hline Croatia & $9.7 \%$ & $11.0 \%$ & $11.4 \%$ & $7.0 \%$ \\
\hline Cyprus & $13.9 \%$ & $15.7 \%$ & $14.2 \%$ & $10.4 \%$ \\
\hline Czech Republic & $15.0 \%$ & $13.3 \%$ & $11.1 \%$ & $8.4 \%$ \\
\hline Denmark & $15.0 \%$ & $13.4 \%$ & $13.5 \%$ & $9.3 \%$ \\
\hline Estonia & $13.2 \%$ & $11.3 \%$ & $9.6 \%$ & $5.4 \%$ \\
\hline Finland & $18.8 \%$ & $18.9 \%$ & $18.6 \%$ & $14.4 \%$ \\
\hline France & $16.1 \%$ & $14.9 \%$ & $15.0 \%$ & $11.7 \%$ \\
\hline Germany & $16.4 \%$ & $15.5 \%$ & $15.1 \%$ & $11.0 \%$ \\
\hline Greece & $10.8 \%$ & $11.5 \%$ & $11.7 \%$ & $8.4 \%$ \\
\hline Hungary & $10.1 \%$ & $10.3 \%$ & $10.4 \%$ & $6.0 \%$ \\
\hline Ireland & $13.0 \%$ & $13.7 \%$ & $13.2 \%$ & $10.4 \%$ \\
\hline Italy & $15.4 \%$ & $13.3 \%$ & $13.5 \%$ & $8.3 \%$ \\
\hline Latvia & $12.6 \%$ & $12.6 \%$ & $11.6 \%$ & $7.7 \%$ \\
\hline Lithuania & $9.8 \%$ & $9.4 \%$ & $8.5 \%$ & $4.4 \%$ \\
\hline Luxembourg & $20.3 \%$ & $15.6 \%$ & $14.5 \%$ & $11.2 \%$ \\
\hline Malta & $14.9 \%$ & $14.2 \%$ & $15.0 \%$ & $11.2 \%$ \\
\hline Netherlands & $12.3 \%$ & $11.3 \%$ & $12.0 \%$ & $10.8 \%$ \\
\hline Poland & $11.5 \%$ & $10.2 \%$ & $8.9 \%$ & $5.0 \%$ \\
\hline Portugal & $19.3 \%$ & $15.5 \%$ & $16.6 \%$ & $9.4 \%$ \\
\hline Romania & $4.8 \%$ & $5.9 \%$ & $4.9 \%$ & $2.5 \%$ \\
\hline Slovakia & $7.9 \%$ & $9.4 \%$ & $7.0 \%$ & $3.6 \%$ \\
\hline Slovenia & $13.6 \%$ & $15.6 \%$ & $14.0 \%$ & $9.2 \%$ \\
\hline Spain & $15.6 \%$ & $14.3 \%$ & $13.7 \%$ & $8.4 \%$ \\
\hline Sweden & $12.6 \%$ & $13.5 \%$ & $12.6 \%$ & $10.3 \%$ \\
\hline United Kingdom & $13.7 \%$ & $16.0 \%$ & $17.1 \%$ & $13.4 \%$ \\
\hline
\end{tabular}

Source: Eurostat (2015), own calculation. 


\section{Structure of Expenditures on Transport Over the Life Cycle of European Households}

The expenditures on transport can be disaggregated into expenditures for the purchase of vehicles, costs for the operation of personal transport equipment, as well as expenses for transport services. The highest share of expenditures on transport is used for the operation of personal transport equipment. The category accounts for $56.9 \%$ of transport expenditures and $7.0 \%$ of a household's total expenditures within the European Union. Hereby, spare parts and accessories for personal transport equipment, fuels and lubricants, maintenance and repair, as well as other services in respect of personal transport equipment are included. Almost one third of the expenditures in transport (31.7\%) are allocated to the purchase of vehicles, which includes cars, motor cycles, bicycles and other vehicles. Those expenditures account on average for $3.9 \%$ of total budget of a European household. For transport services, as passenger transport by railway, road, air, sea and inland waterway or other purchased transport services, only $1.5 \%$ of a household's total expenditures, or $12.2 \%$ of all expenditures in the field of transport, аге used (see Figure 4).

Figure 4. Structure of average expenditures on transport of European households, 2010

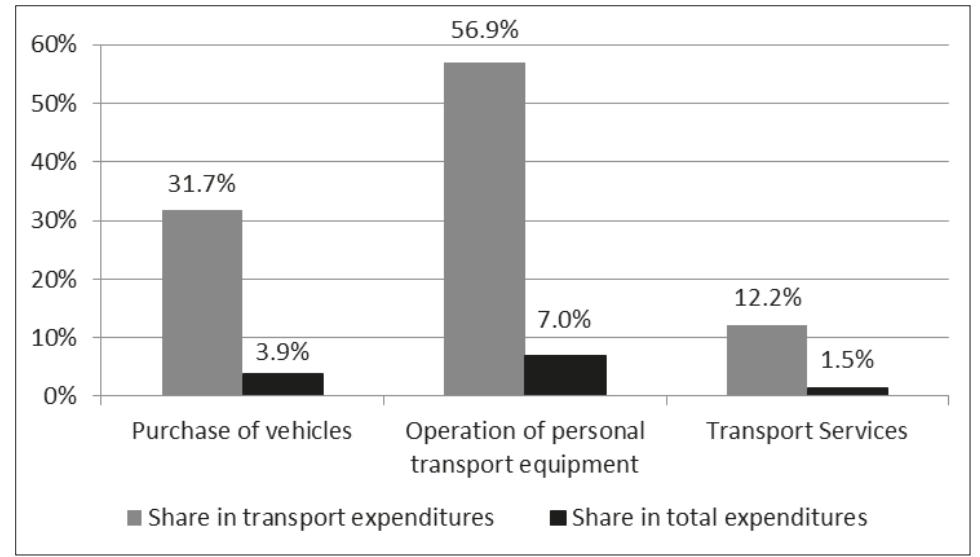

Note: Due to rounding, the sum of the listed individual positions may be higher/lower than 100\%.

Source: Eurostat (2015), own calculation.

There areagainessential differences in the expenditure behaviour of households within the 28 member countries of the European Union. For example, the expenditure share for the purchase of vehicles in total expenditures by households varies between less than $1 \%$ in Bulgaria (0.1\%), Romania (0.3\%), Lithuania (0.7\%), and Slovakia (0.8\%) and more than 7\% in Cyprus (7.4\%) and Luxembourg (7.7\%). For expenditures on the operation of personal transport equipment the range is lower, with a minimum of $3.1 \%$ in Romania and a maximum of $9.3 \%$ in Portugal. The highest expenditure share for transport services is reached in the United Kingdom with $2.3 \%$ and the lowest one in 
Slovenia with $0.6 \%$. In some countries even the relevance of the consumption classes in transport is deviating from the presented European average (e.g. higher expenditures on the purchase of vehicles than the operation of personal transport equipment; see Table A1 in the appendix). As already mentioned in chapter 2, (relative) prices of the goods and services, their availability, the settlement structure within the countries as well as topographic characteristics of the countries and cultural habits can be stated as potential reasons for the differing structure in consumption expenditures for transport.

Having in mind the downturn of the expenditure share for transport at higher ages, it seems of interest, to have a look if all consumption classes are affected equally. As Figure 5 shows, the transport expenditures of a household are slightly redistributed over a household's life cycle. The operation of personal transport equipment gains steadily in importance, from $51.8 \%$ at younger ages to $58.9 \%$ at higher ages. At the same time, the purchase of vehicles increases up to middle age and decrease thereafter, from $33.1 \%$ in the age category from 30 to 44 years to $30.5 \%$ in retirement age. Regarding transport services, the highest share is reached by the youngest age group (16.3\%) and it decreases to levels between $11.0 \%$ and $12.7 \%$ at higher ages. For the aggregate European household, hence, expenditures for transport services as well as the purchase of vehicles decrease above the average rate over the life cycle, while the decrease in expenditures for the operation of personal transport equipment is below the average rate. To be more specific, in general, the budget share for transport decreases by $29.1 \%$ at retirement age compared to middle age. While the expenditure share for the operation of personal transport equipment in total consumption expenditures decreases by $27.3 \%$ only, the ones for transport services and the purchase of vehicles decrease by $35.3 \%$ and $31.0 \%$, respectively (see Figure A1 in the appendix).

Figure 5. Structure of expenditures on transport over the life cycle of European households, 2010

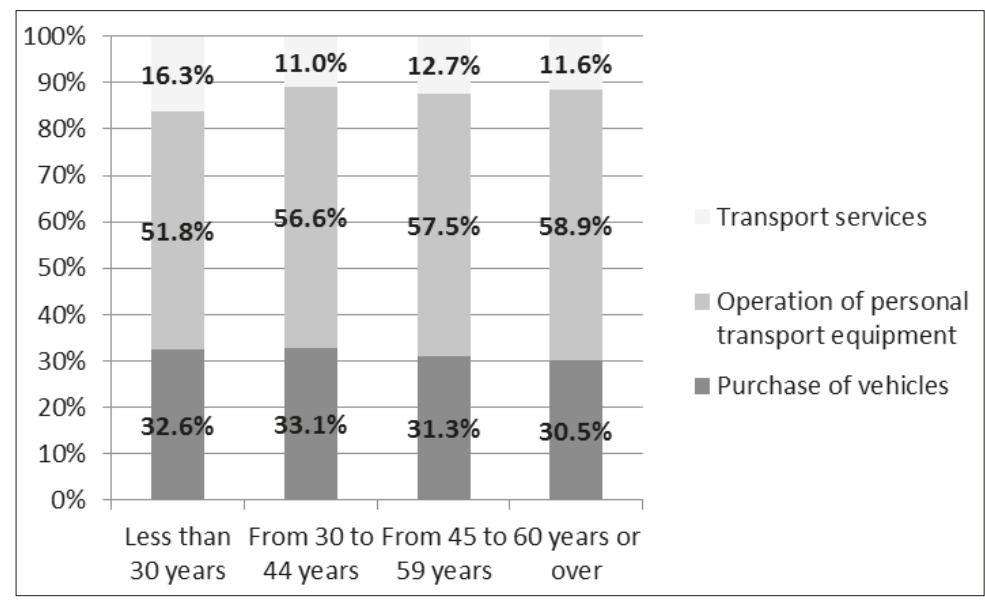

Note: Due to rounding, the sum of the listed individual positions may be higher/lower than 100\%. Source: Eurostat (2015), own calculation. 
Rather surprising in the results on the structure of transport expenditures is the decrease in expenditures on transport services in retirement age, as one might expect the opposite, an increase in the use of transport services, e.g. due to health-related limitations in mobility. An analysis for Germany shows an obvious increase of the consumption category for transport services in relation to total expenditures for transport at higher age (Aigner-Walder and Döring, 2014). Also an analysis by Currie and Delbosc (2009) suggests that those aged 60 years and over reduce public transport trip rates substantially less than overall trip rates (16\% and 30\%, respectively) compared to those aged below 60 . Hence, it seems of interest to take a closer glimpse on the expenditures for transport services of households at retirement age in our data.

In Figure 6 the change of the expenditure share for transport services at retirementage isshown. Hereby, axis xshows the change in the share oftransport expenditures and axis y the change in the share of total expenditures. As shown in Figure 6, in some countries (including Germany) the share of transport services in transport expenditures increases at retirement age, whereby the highest increase was found in Romania and Bulgaria. But in 15 countries out of the 28, expenditures for transport services loose in relevance, compared to the other two transport categories. Nevertheless, as the expenditures in transport in total decreases at retirement age compared to middle age (4559 years), the demand in transport services in total expenditures decreases in almost all observed countries. The only exceptions are Finland and Austria where an increase in the share of transport services in total expenditures is clearly visible, meaning that transport services gain of relevance from middle to higher age. For Germany a constant development is identified.

Figure 6. Change of expenditure share for transport service from middle to retirement age, 2010

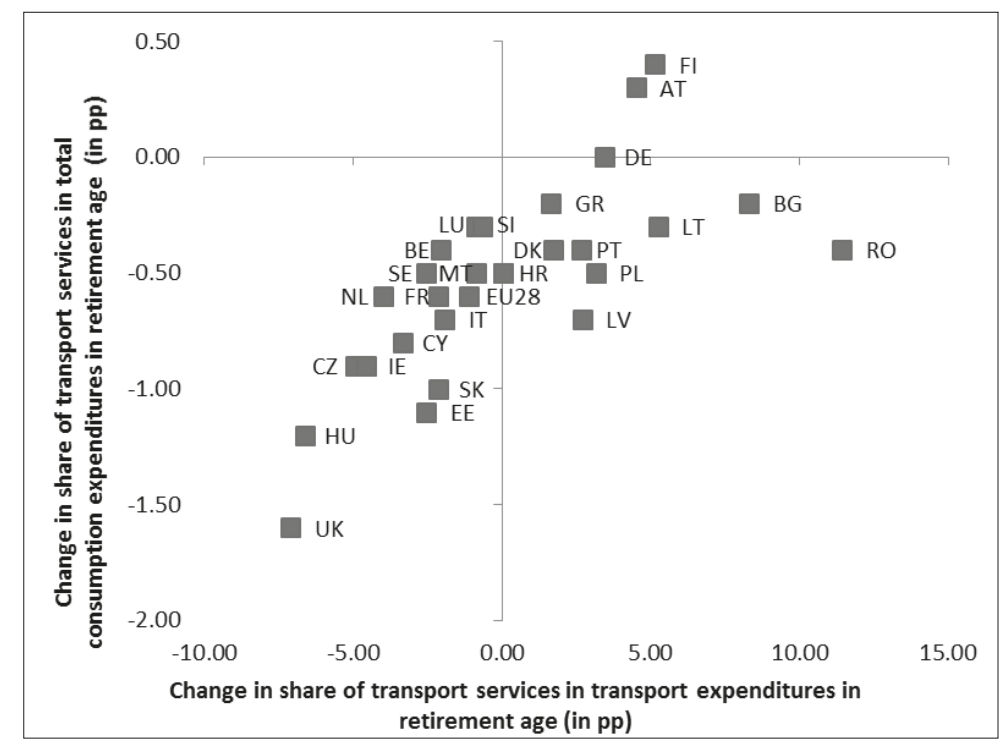

Source: Eurostat (2015), own calculation and illustration. 
Summing up, we find a differing structure in transport expenditures over the life cycle of households within the European Union. The reduction of expenditures for transport at retirement age leads in general to a decrease of expenditures in all three expenditure categories of transport, although the decrease in the operation of personal transport equipment is lower compared to the two other categories. Due to the differing levels and structure of transport expenditures within the countries, country-specific differences have to be taken into account. So we find, for example, in three out of the 28 countries no decrease of expenditures for transport services in total expenditures, namely in Finland, Austria and Germany.

\section{Discussion of Results}

According to the theoretical discussion in chapter 2 , a decrease of expenditures in the transport sector from middle to retirement age could already be expected. The reduction of work related expenses leads to a decrease of expenditures at the retirement age in general. In particular, expenditures for goods and services in the field of transport as well as clothing and restaurants are mentioned as the main determinants (Hurst, 2008; Aguila, Attanasio and Meghir, 2008). From the perspective of transportation, without work obligations the daily commuting to work and back home is not needed anymore, leading to a decrease of expenditures. Besides the reduction of work related mobility, also reduced mobility of older people due to health limitations could be a reason for the existing structure of expenditures for transport over the life cycle (Banks, Blundell and Tanner, 1998). Ziems et al. (2010) also find that in terms of preferences, older people derive greater utility from in-home activities. The mentioned arguments can also be applied to the expenditure structure within the transport sector. As the use of transport facilities decreases, the expenses for transport services decrease, as well as potential investments in cars in the sense of the purchase of vehicles. On the other hand, the costs for the operation of existing personal transport equipment are - relatively seen - increasing in importance. A potential reason could be that households are not willing to purchase a vehicle anymore, due to its reduced use and uncertainty in life expectancy, with the consequence of spending more for repairing the existing one(s).

The results suggest that the shift from a younger to an older population within the EU could lead - under the analysed expenditure pattern for transport to a reduction in aggregate demand for goods and services in the field of transport on the European market. This would also affect the production in the transport sector. Hereby, it has to be considered that transport is not only influencing the private sector but the public sector as well, as streets and transport services are commonly provided by the state. But a reduced demand in transportation would also have potential positive public effects. On the one hand, a reduction in $\mathrm{CO}_{2}$ emissions would be the consequence of less demand in transportation facilities (Kluge et al., 2014). On the other hand, the decrease of work related expenditures and especially mobility, could lead to an increase in economic growth within the living region of 


\section{Birgit Aigner, Thomas Döring}

retired people due to the shift in demand for regionally offered products and services (Mayerhofer, Aigner and Döring, 2010).

There are still some uncertainties which have to be considered regarding the future development of the demand for transport goods and services: On the one hand, there is a high probability that the expenditure structure of future households at retirement age will differ from those households which are in retirement nowadays. Except for changes in lifestyles and potential effects of an increased (healthier) life expectation, also technological progress in the sense of new products and services has to be considered. Analyses show that cohort effects seem to play a comparable role to age effects. Wakabayashi and Hewings (2007) found a high influence of such cohort effects in the transport sector. Currie and Delbosc (2010) show for example an increasing holding of licences in the age group over 60 and a small increasing longitudinal trend towards public transport use with Australian data.

Figure 8. Average household consumption expenditures for transport by age in EU15 (in PPS), 1994, 1999 and 2010

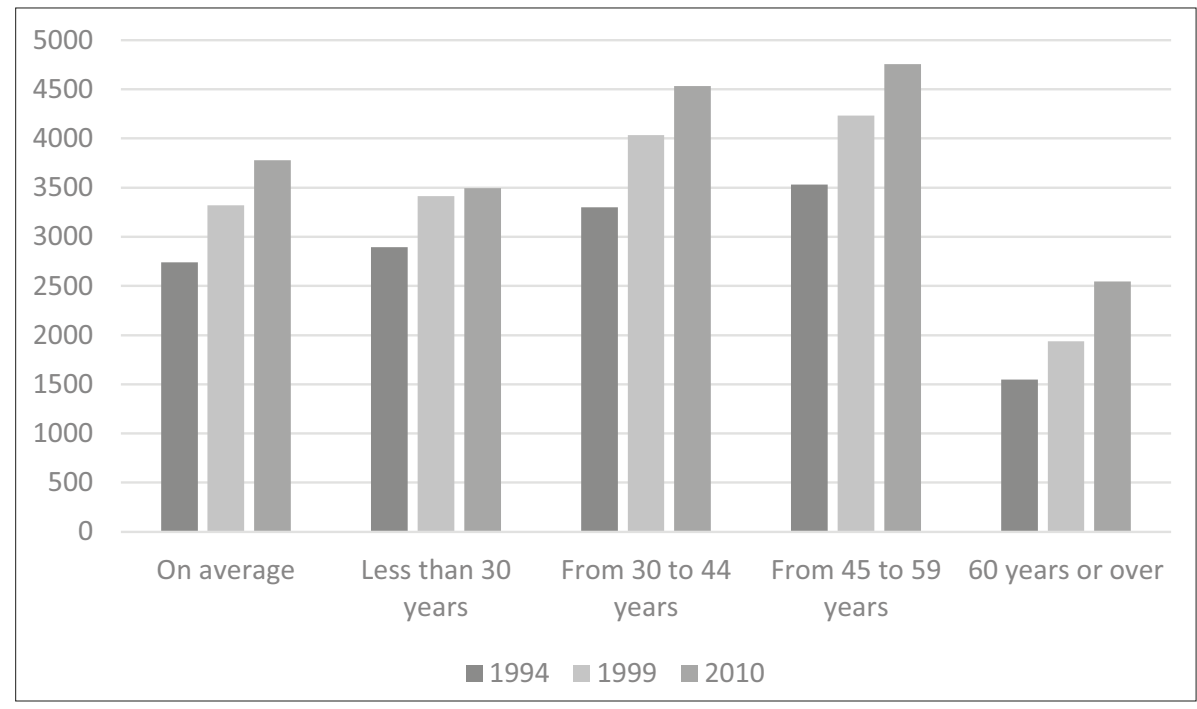

Source: Eurostat (2015), own calculation.

A comparison of the mean consumption expenditure per household in the EU15 countries based on previous consumer expenditure surveys suggests an increase in expenditures for transport over the time within all age categories. From 1994 to 2010 the expenditures for transport increased on average by approx. 40\%. But this considerable average increase is mainly driven by the households over 60 years with an increase of almost $65 \%$. Households of the age category under 30 years show the lowest increase of $20.1 \%$. But Fig. 8 once more highlights the gap between households over 60 years and younger households in consumption expenditure of transport goods and services. A more detailed look at the data reveals that households over 60 years doubled expenditures for the operation of personal transport equipment from 1994 
to 2010. Furthermore, they showed the highest increase in expenditures for the purchase of vehicles, while expenditures for transport services increased only modestly compared to the other age groups (Eurostat, 2015).

Besides changing habits in consumption expenditures over time, also changes in income or prices could lead to substantial differences in the expenditure structure. For example, previous results show a high expenditure elasticity for transport, especially at younger ages (Yoon and Hewings, 2006; Wakabayashi and Hewings, 2007; Aigner-Walder, 2012). This means that expenditures for transportation goods and services rise disproportionally in the case of an increase of expenditures of the household. Such an increase of consumption expenditures could be triggered by an increase of income of the household. As especially younger age cohorts could profit in earnings from the demographic change due to lacking (younger) labour force, this would affect the demand for transport services positively. This could balance or even over compensate the direct negative effect of the aging of the population on expenditures in transport services and goods (Lehmann, 2004; Deutsche Bank Research, 2007; Aigner-Walder, 2015). Regarding prices, especially the (relative) price of oil as well as alternative modes of transportation (e.g. electric cars) are of relevance for consumption expenditure decisions in the transport sector.

\section{Overall Conclusions and Public Sector Consequences}

As the results of the paper show, the share in consumption expenditures for goods and services in the field of transport decreases at retirement age. A reduction in relative expenditures is visible for the average household within the European Union, as well as within all EU28 countries. More than half of the expenditures for transport are spent for the operation of personal transport equipment, almost one third for the purchase of vehicles and the remaining 12\% for transport services. But also the structure of expenditures in transport goods and services varies over a household's life cycle. Especially the expenditures for transport services as well as the purchase of vehicles decrease in retirement, whereas we see a lower decrease for the operation of personal transport equipment; but country-specific differences are visible.

The results of the analysis suggest a decrease of expenditures in the field of transport by private households due to the ageing of the population. The potential negative effects could be reduced by cohort effects, meaning an increase in expenditures for transport goods and services over the time, due to changing preferences and lifestyles of households as well as technological progress. Furthermore, indirect effects of the ageing of the population, as a potential redistribution of income to younger age cohorts, or changes in (relative) prices have to be taken into account.

For public authorities these results are of relevance for various reasons: On the one hand, a reduction in the demand of goods and services in the field of transport would have positive consequences in the sense of a reduction of greenhouse gases. On the other hand, the changed consumption structure 


\section{Birgit Aigner, Thomas Döring}

by age should be considered in the supply of transportation infrastructure and services. Moreover, changes in the consumption structure of private households will directly affect the economic structure of an economy, including not only the demand for goods and services but also human capital.

FH-Prof. Dr. Birgit Aigner-Walder is a professor for Economics and the head of the Department Demographic Change and Regional Development of the Institute for Applied Research on Ageing (IARA) at Carinthia University of Applied Sciences.

Prof. Dr. Thomas Doering is a professor of Politics and Institutions and the head of the Centre for Research and Development as well as the head of the Service-Centre for Research and Technology-Transfer at Darmstadt University of Applied Sciences. 


\section{References:}

Aguila, E., Attanasio, O.P., Meghir, C. (2008). Changes in Consumption at Retirement. RAND Working Paper, WR-621.

Aigner-Walder, B. (2012). Demographischer Wandel und privater Konsum. Analyse der Auswirkungen anhand eines Nachfragemodells für Österreich. SVH, Saarbrücken .

Aigner-Walder, B. (2015). Effects of the Demographic Changes on Private Consumption: An Almost Ideal Demand System Analysis for Austria. Journal of Economic and Social Studies (5), 33-57.

Aigner-Walder, B., Döring, T. (2012). The Effects of Population Ageing on Private Consumption - A Simulation for Austria based on Household Data up to 2050. Eurasian Economic Review (2), 63-80.

Aigner-Walder, B., Döring, T. (2014). Wie beeinflusst der demografische Wandel die privaten Verkehrsausgaben? Wirtschaftsdienst (94), 432-438.

Banks, J., Blundell, R., Tanner, S. (1998). Is there a Retirement-Savings Puzzle? The American Economic Review (88), 769-788 .

Bundesministerium für Familie, Senioren, Frauen und Jugend (2007). Wirtschaftsmotor Alter. Endbericht. Berlin.

Buslei, H., Schulz, E., Steiner, V. (2007). Auswirkungen des demographischen Wandels auf die private Nachfrage nach Gütern und Dienstleistungen in Deutschland bis 2050. DIW Deutsches Institut für Wirtschaftsforschung, Berlin.

Currie, G., Delbosc, A. (2010). Exploring public transport usage trends in an ageing population. Transportation (37), 151-164 .

Deaton, A., Paxson, C. (1994). Saving, Growth, and Aging in Taiwan. In: Wise, D. A. (ed.) Studies in the Economics of Aging, pp. 331-361. University of Chicago Press, Chicago.

Deutsche Bank Research (2007). Wie werden ältere Deutsche ihr Geld ausgeben? Wie demographische Entwicklungen, Wachstum und sich ändernde Verbraucherpräferenzen zusammenspielen. Aktuelle Themen 385. Frankfurt am Main.

Dynan, K., Edelberg, W., Palumbo, G. (2009). The Effects of Population Ageing on the Relationship among Aggregate Consumption, Saving, and Income. American Economic Review: Papers \& Proceedings (99), 380-386.

European Commision (2015). The 2015 Ageing Report. Economic and budgetary projections for the 28 EU Member States (2013-2060). European Economy $3 \mid 2015$.

Eurostat (2015). Household budget surveys. http://ec.europa.eu/eurostat/web/ household-budget-surveys Accessed 15 August 2015.

Eurostat (2017). Population structure and ageing. In: Europe in figures - Eurostat yearbook. http://ec.europa.eu/eurostat/statistics-explained/index.php/ Population_structure_and_ageing\#Publications Accessed 11 September 2017.

Evans, M., Jamal, A., Foxall, G. (2009). Consumer Behaviour. 2nd Edition. Wiley, West Sussex.

Fernández-Villaverde, J., Krueger, D. (2002). Consumption over the Life Cycle: Some Facts from Consumer Expenditure Survey Data. PIER Working Paper 02-044. Penn Institute for Economic Research, Philadelphia. 


\section{Birgit Aigner, Thomas Döring}

Foot, D.K., Gomez, R. (2006). Population Ageing and Secoral Growth: The Case of the U.K., 2006-2026. Oxford Journal of Business \& Economics (5), 1-17.

Hurd, M.D., Rohwedder, S. (2005). The Retirement-Consumption Puzzle. Anticipated and Actual Declines in Spending at Retirement. RAND Labor and Population Working Paper, WR-242.

Hurst, E. (2008). The retirement of a consumption puzzle. NBER Working Paper 13789.

Keynes, J.M. (1936). The General Theory of Employment Interest and Money. Harcourt, Brace and Company, New York.

Kluge, F., Zaghen, E., Loichinger, E., Vogt, T. (2014). The Advantages of Demographic Change after the Wave: Fewer and Older, but Healthier, Greener, and More Productive? PLOS ONE 9.

Lehmann, H. (2004). Auswirkungen demografischer Veränderungen auf Niveau und Struktur des Privaten Verbrauchs - eine Prognose für Deutschland bis 2050. Institut für Wirtschaftsforschung Halle, Diskussionspapier Nr. 195.

Lührmann, M. (2009). Consumer Expenditures and Home Production at Retirement - New Evidence from Germany. German Economic Review (11), 225-245.

Mankiw, N.G., Taylor, M.P. (2014). Economics, $3^{\text {rd }}$ Edition. Thomson Learning, London.

Martins, J.O. et al. (2005). The Impact of Ageing on Demand, Factor Markets and Growth, OECD Economics Department Working Papers 420, OECD Publishing.

Mayerhofer, P., Aigner, B., Döring, T. (2010). Demographischer Wandel als Herausforderung für Österreich und seine Regionen - Teilbericht 1: Räumliche Charakteristika des demographischen Wandels. WIFO, Wien.

Modigliani, F. (1986). Life Cycle, Individual Thrift, and the Wealth of Nations. The American Economic Review (76), 297-313.

Modigliani, F., Brumberg, R. (1966). Nutzenanalyse und Konsumfunktion. In: Streissler, E., Streissler, M. (eds.) Konsum und Nachfrage, pp. 319-337. Kiepenhever \& Witsch, Köln, Berlin.

Pindyck, R.S., Rubinfeld, D.L. (2005). Mikroökonomik. 6. Auflage. Pearson, München.

Schimany, P. (2003). Die Alterung der Gesellschaft. Ursachen und Folgen des demographischen Umbruchs. Campus Verlag, Frankfurt, New York.

Solomon, M.R. (2014). Consumer Behavior: Buying, Having and Being. Prentice Hall.

United Nations, Department of Economic and Social Affairs, Population Division (2013). World Population Prospects: The 2012 Revision. CD-ROM Edition.

Wakabayashi, M., Hewings, G. (2007). Life-Cycle Changes in Consumption Behavior: Age-Specific and Regional Variations. Journal of Regional Sciences (42), 315-337.

Woeckener, B. (2006). Einführung in die Mikroökonomik. Gütermärkte, Faktormärkte und die Rolle des Staates. Springer, Berlin, Heidelberg.

Yoon, S.G., Hewings, G.J.D. (2006). Impacts of Demographic Changes in the Chicago Region. Regional Economics Applications Laboratory (REAL)

Discussion Papers 06-T-7. University of Illinois, Urbana. 
Reduced Consumption within the Transport Sector due to the Ageing of the Population? An Analysis of Expenditures of Private Households within the European Union

Ziems, S., Konduri, K., Sana, B. , Pendyala, R. (2010). Exploration of Time Use Utility Derived by Older Individuals from Daily Activity-Travel Patterns. Transportation Research Record (2156), 111-119. 


\section{Appendix}

Table A1. Average structure of expenditures on transport relative to total consumption expenditures of private households in the EU28 countries, 2010

\begin{tabular}{|c|c|c|c|}
\hline Country & $\begin{array}{l}\text { Purchase of } \\
\text { vehicles }\end{array}$ & $\begin{array}{l}\text { Operation of personal } \\
\text { transport equipment }\end{array}$ & $\begin{array}{l}\text { Transport } \\
\text { Services }\end{array}$ \\
\hline Austria & $5.8 \%$ & $8.1 \%$ & $1.1 \%$ \\
\hline Belgium & $4.9 \%$ & $7.1 \%$ & $1.0 \%$ \\
\hline Bulgaria & $0.1 \%$ & $3.9 \%$ & $1.3 \%$ \\
\hline Croatia & $1.7 \%$ & $6.8 \%$ & $1.1 \%$ \\
\hline Cyprus & $7.4 \%$ & $5.3 \%$ & $1.3 \%$ \\
\hline Czech Republic & $3.0 \%$ & $6.6 \%$ & $1.5 \%$ \\
\hline Denmark & $4.1 \%$ & $6.3 \%$ & $1.9 \%$ \\
\hline Estonia & $2.5 \%$ & $5.3 \%$ & $1.9 \%$ \\
\hline Finland & $7.0 \%$ & $8.3 \%$ & $2.1 \%$ \\
\hline France & $6.5 \%$ & $6.0 \%$ & $1.6 \%$ \\
\hline Germany & $4.7 \%$ & $8.5 \%$ & $1.4 \%$ \\
\hline Greece & $3.6 \%$ & $5.8 \%$ & $1.2 \%$ \\
\hline Hungary & $2.6 \%$ & $4.9 \%$ & $1.5 \%$ \\
\hline Ireland & $4.4 \%$ & $6.5 \%$ & $1.9 \%$ \\
\hline Italy & $2.8 \%$ & $7.7 \%$ & $1.1 \%$ \\
\hline Latvia & $1.2 \%$ & $7.5 \%$ & $2.2 \%$ \\
\hline Lithuania & $0.7 \%$ & $6.4 \%$ & $1.0 \%$ \\
\hline Luxembourg & $7.7 \%$ & $5.8 \%$ & $1.0 \%$ \\
\hline Malta & $4.0 \%$ & $8.3 \%$ & $1.5 \%$ \\
\hline Netherlands & $4.0 \%$ & $5.9 \%$ & $1.5 \%$ \\
\hline Poland & $2.0 \%$ & $5.4 \%$ & $1.3 \%$ \\
\hline Portugal & $3.9 \%$ & $9.3 \%$ & $1.3 \%$ \\
\hline Romania & $0.3 \%$ & $3.1 \%$ & $1.3 \%$ \\
\hline Slovakia & $0.8 \%$ & $4.8 \%$ & $1.5 \%$ \\
\hline Slovenia & $5.9 \%$ & $6.7 \%$ & $0.6 \%$ \\
\hline Spain & $3.7 \%$ & $7.4 \%$ & $1.2 \%$ \\
\hline Sweden & $4.2 \%$ & $6.4 \%$ & $1.5 \%$ \\
\hline United Kingdom & $4.6 \%$ & $8.4 \%$ & $2.3 \%$ \\
\hline
\end{tabular}

Source: Eurostat (2015), own calculation 
Reduced Consumption within the Transport Sector due to the Ageing of the Population? An Analysis of Expenditures of Private Households within the European Union

Figure A1. Average structure of consumption in transport relative to total consumption expenditures over the life cycle of European households, 2010

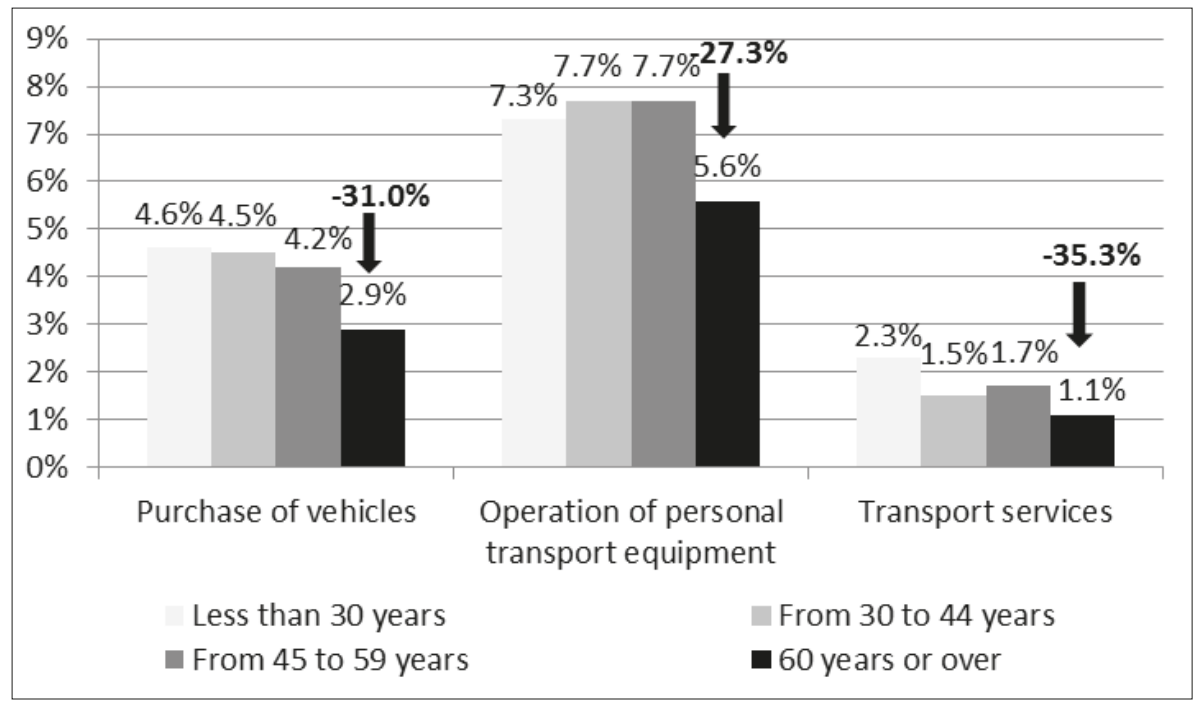

Source: Eurostat (2015), own calculation. 


\section{Zaradi staranja prebivalstva zmanjšana potrošnja za promet? Analiza izdatkov zasebnih gospodinjstev v Evropski uniji in možne implikacije za javni sektor}

Staranje prebivalstva bo imelo različne učinke na gospodarstvo. To vključuje tako učinke na strukturo izdatkov zasebnih gospodinjstev kot tudi učinke na trg dela in javne proračune. Potrošniško vedenje gospodinjstev se močno razlikuje glede na starost zaradi različnih želja in potreb. Mladi imajo, denimo, višje izdatke na področju izobraževanja, starejši pa potrebujejo več zdravstvenih izdelkov in storitev. Poleg tega se struktura potrošnje razlikuje glede na starostne skupine tudi zaradi primerljivega zgodovinskega, gospodarskega oz. družbenega ozadja teh ljudi. Na razlike v strukturi potrošnje glede na starost so empirično pokazale različne študije. Njihove glavne ugotovitve so precej podobne: delež izdatkov za nastanitev, vodo in gorivo ter zdravje se z leti povečuje, stroški za prevoz pa so pri višjih starostih nižji. Napovedi učinkov staranja prebivalstva na skupno povpraševanje zasebnih gospodinjstev predvidevajo povečanje deleža proračunskih sredstev za zdravje in nastanitev, delež potrošnje v prometnem sektorju pa se bo po pričakovanjih znižal.

Pričujoči članek izpostavlja vprašanje, kako se skozi življenje spreminjajo izdatki za izdelke in storitve na področju prevoza, in predstavlja možne implikacije staranja prebivalstva za skupno povpraševanje v prometnem sektorju. V predmetni analizi so uporabljeni podatki o potrošniških izdatkih gospodinjstev in sociodemografske spremenljivke, npr. starost gospodinjstva. Potrebni primerljivi podatki za vseh 28 držav so bili pridobljeni iz anket o porabi v gospodinjstvih (HBS) v državah članicah Evropske unije. Ankete HBS so nacionalne vzorčne raziskave gospodinjstev, ki se izvajajo v vseh državah članicah EU in se osredotočajo na izdatke gospodinjstev za različne vrste potrošniškega blaga in storitev v določenem času.

Rezultati kažejo, da reprezentativno gospodinjstvo v Evropski uniji v povprečju 12,3 \% vseh izdatkov nameni za izdelke in storitve na področju prevoza, vendar se delež razpoložljivih sredstev, ki jih gospodinjstva porabijo za prevoz, med državami članicami EU močno razlikuje: najmanjši je v Bolgariji (4,6 \%), največji pa na Finskem (17,5 \%). Izdatke za prevoz je mogoče razdeliti na izdatke za nakup vozil, operativne stroške osebnih prevoznih sredstev in stroške prevoznih storitev. Največji delež izdatkov za prevoz predstavlja obratovanje osebnih prevoznih sredstev. Ta kategorija predstavlja 56,9 \% izdatkov za prevoz in 7,0 \% vseh izdatkov gospodinjstev v Evropski uniji. Skoraj ena tretjina izdatkov za prevoz $(31,7 \%)$ je namenjenih nakupu vozil. Ti izdatki v povprečju predstavljajo 3,9 \% vseh razpoložljivih sredstev v evropskem gospodinjstvu. Prevozne storitve, tj. potniški prevoz po železnici, cestah, 
zraku, morju in celinskih plovnih poteh oz. drugi stroški prevoznih storitev, predstavljajo zgolj $1,5 \%$ vseh izdatkov gospodinjstev ali $12,2 \%$ vseh izdatkov na področju prometa.

Zmanjšanje zasebnih izdatkov za prevozne izdelke in storitve je - skladno s predhodnimi empiričnimi rezultati - pri gospodinjstvih v Evropski uniji jasno zaznavno. Gospodinjstva s člani, mlajšimi od 30 let, 14,1 \% vseh izdatkov namenijo za prevoz, ta delež pa rahlo pade že pri skupini ljudi, starih od 30 do 44 let $(13,6 \%)$, in pri ljudeh, starih od 45 do 59 let (13,4\%). Gospodinjstva s člani, starimi 60 ali več, porabijo precej manj za prevoz - delež izdatkov se zmanjša za skoraj štiri odstotne točke, na 9,5\%. To zmanjševanje izdatkov za prevoz v upokojitveni starosti je mogoče zaznati v vseh državah članicah EU. V povprečnem evropskem gospodinjstvu do zmanjšanja izdatkov prihaja v vseh treh kategorijah izdatkov za prevoz, čeprav je zmanjšanje pri obratovanju osebnega prevoznega sredstva manjše kot v drugih dveh kategorijah. Poleg zmanjšanja mobilnosti v zvezi z delom je za takšno strukturo izdatkov za prevoz skozi celotno življenjsko dobo lahko odgovorno tudi zmanjšanje mobilnosti starejših zaradi zdravstvenih omejitev ali povečanje števila dejavnosti na domu pri višjih starostih.

Rezultati kažejo, da bi staranje prebivalstva v EU lahko povzročilo - skladno z analiziranim vzorcem izdatkov za prevoz-zmanjšanje skupnega povpraševanja za izdelke in storitve na področju prometa na evropskem trgu. Ti rezultati so za državne organe pomembni zaradi več razlogov. Po eni strani bi zmanjšanje povpraševanja po izdelkih in storitvah na področju prometa imelo pozitivne posledice zaradi zmanjšanja emisij toplogrednih plinov, po drugi strani pa bi bilo treba spremenjeno strukturo potrošnje glede na starost upoštevati tudi pri zagotavljanju prometne infrastrukture in storitev. Poleg tega bodo spremembe strukture potrošnje zasebnih gospodinjstev neposredno vplivale tudi na ekonomsko strukturo gospodarstva, torej tako na povpraševanje po izdelkih in storitvah kot tudi na človeški kapital.

Ključne besede: izdatki gospodinjstev, zasebna poraba, pretok blaga in storitev, staranje, javni prevoz. 